НАУКОВИЙ ВІСНИК

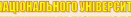
tific messenger of 2. 411 IIIII Tos Том 21 № 92 2019
Науковий вісник Аьвівського національного університету ветеринарної медицини та біотехнодогій імені С.3. Гжицького. Серія: Харчові технологіі

Scientific Messenger of Lviv National University of Veterinary Medicine and Biotechnologies.

Series: Food Technologies

\title{
The use of pumpkin crumbs in pate technology and their functional characteristics
}

I.M. Basarab, U.R. Drachuk, I.S. Romashko, B.I. Halukh, I.I. Simonova, L.K. Moldavanova

Stepan Gzhytskyi National University of Veterinary Medicine and Biotechnologies Lviv, Ukraine

Article info

Received 05.09.2019

Received in revised form 08.10 .2019

Accepted 09.10.2019

Stepan Gzhytskyi National University of Veterinary Medicine and Biotechnologies Lviv, Pekarska Str., 50, Lviv, 79010, Ukraine.

Tel.: +38-097-270-10-36 E-mail:tmmozv@ukr.net
Basarab, I.M., Drachuk, U.R., Romashko, I.S., Halukh, B.I., Simonova, I.I., \& Moldavanova, L.K. (2019). The use of pumpkin crumbs in pate technology and their functional characteristics. Scientific Messenger of Lviv National University of Veterinary Medicine and Biotechnologies. Series: Food Technologies, 21(92), 23-27. doi: 10.32718/nvlvet-f9205

One of the priorities of the modern meat industry is the production of products that have improved consumer properties. To accomplish this task, it is necessary to involve as much as possible in industrial circulation the local raw materials of plant origin, which will be an impetus for the production of new foods with functional properties. The article deals with the partial replacement of raw materials of animal origin with pumpkin pulp as a functional ingredient in the production of paté products. We have developed three recipes for pumpkin paste. Changes in nutritional value of the developed samples were investigated. The organoleptic characteristics and nutritional value of pumpkin pate products were determined. The use of pumpkin pulp as a functional ingredient in the technology of pate products affects the appearance, the color of the products and the composition of these products, along with other technological indicators were within the regulatory requirements. Experimentally established, that increase in the proportion of pumpkin pulp has been found to lead to an increase in mineral content and a decrease in fat content. Improvements in the functional and technological properties of experimental pâté products based on the use of pumpkin pulp have been demonstrated. Established rational replacement level of basic raw materials, which is characteristic for recipes № 3. Pâté products using pumpkin pulp as a functional ingredient is a low-calorie products. The production of combined meat products does not require additional specialized equipment and is a potential source of expansion of the domestic range of functional products. Consumption of these products gives us every reason to believe their food with significant new functional properties that meet the requirements of modern food.

Key words: pâté products, pumpkin pulp, formulations, functional products, organoleptic characteristics, nutritional value, functional and technological properties.

\section{Використання м'якуша гарбуза у технології паштетних виробів та їх функціональні характеристики}

\footnotetext{
І.М. Басараб, У.Р. Драчук, І.С. Ромашко, Б.І. Галух, І.І. Сімонова, Л.К. Молдаванова

Львівський національний університет ветеринарної медицини та біотехнологій імені С.3. Гжицького, м. Львів, Україна

Одним із пріоритетних завдань сучасного м'ясної галузі є випуск продукції, яка вирізняється покращеними споживними властивостями. Для виконання цьього завдання необхідно максимально залучити в промисловий обіг місцеві сировинні ресурси рослинного походження, щчо стане поштовхом для виробництва нових функиіональних продуктів харчування. У роботі висвітлені питання часткової заміни сировини тваринного походження на м'якуш гарбуза як функціонального інгредієнта при виробництві паштетних виробів. Розроблено три рецептури паштетних виробів із м'якушем гарбуза. Досліджено зміни харчової иінності розроблених зразків. Визначено органолептичні показники та харчову иінність паштетних виробів з м'якушем гарбуза. Застосування м'якуша гарбуза як функціонального інгредієнта в технології паштетних виробів впливає на зовнішній вигляд, колір продуктів, позначається на складі даної продукиї, поряд із циим інші технологічні показники перебувають у межах нормативних вимог. Вста-
} 
новлено, щзо збільшення частки м'якуша гарбуза призводить до збільшення вмісту мінеральних речовин та зниження вмісту жиру. Доведено поліпшення функціонально-технологічних властивостей дослідних паштетних виробів на основі використання м'якуша гарбуза. Встановлено раціональний рівень заміни основної сировини, який характерний для рецептури № 3 . Паштетні вироби із застосуванням м'якуша гарбуза як функціонального інгредієнта є продукцією низькокалорійною. Виробництво комбінованих м'ясних виробів не вимагає додаткового спечіалізованого обладнання та є потениійним джерелом розиирення вітчизняного асортименту функціональних продуктів. Споживання таких виробів дає нам всі підстави вважати їх продуктами харчування з істотно новими функціональними властивостями, які відповідали б сучасним вимогам щзод харчування.

Ключові слова: паштетні вироби, м'якуш гарбуза, рецептури, функціональні продукти, органолептичні показники, харчова цінність, функціонально-технологічні властивості.

\section{Вступ}

Харчування є одним 3 найважливіших чинників, що визначають стан здоров'я населення. Раціональне харчування необхідне для підтримання нормального функціонування здорового організму, створює умови для фізичного та розумового розвитку, забезпечує високу працездатність, сприяє профілактиці захворювань і підвищує здатність організму протистояти дії негативних факторів навколишнього середовища.

Останнім часом спостерігається різке збільшення чисельності хронічних захворювань у населення України, що значною мірою пов'язано 3 порушенням якості харчування. Так, до раціону в значній кількості входять жири тваринного походження і прості вуглеводи, тимчасом як дефіцитним є споживання білків, макро- і мікроелементів, харчових волокон, вітамінів та інших біологічно активних речовин. Складні соціально-економічні умови життя не дають можливості громадянам нашої країни приділяти питанню раціонального харчування належну увагу. Тому проблема здорового харчування повинна вирішуватися підприємствами харчової промисловості шляхом створення продуктів підвищеної біологічної цінності як для роздрібної торгівлі, так і для мережі закладів громадського харчування (Kovalenko, 2019).

Різноманітні паштетні вироби є першими продуктами на основі м'яса, з якими стикаються в своєму житті більшість споживачів: уже в шестимісячному віці, згідно з приписами дієтологів, дитина має одержувати біологічно повноцінні білки, жири, залізо в легкій для засвоювання формі, тобто м'ясо у прийнятній для годування малюків формі дрібнодисперсних паст. Люди похилого віку, багато з яких страждають на різні захворювання органів травлення, також змушені обмежуватися споживанням пюреподібних м'ясних продуктів, яким, аби полегшити перехід від усталеного роками меню, фахівці навіть намагаються надати форму та структуру звичних цільном'язових та грубоподрібнених виробів. Тому доцільним є розроблення паштетів функціонального призначення як для вищезазначених груп населення, так і для профілактики захворювань дорослого населення (Chamova et al., 2006; Kaynash \& Vinnikova, 2007; Kaynash, 2011).

Перспективним напрямком при створенні збагачених харчових продуктів $є$ використання нетрадиційної місцевої сировини, яка $є$ джерелом біологічноактивних речовин, і адаптована до травного раціону пересічного українця. Максимально корисної дії м'ясних продуктів на організм людини можна досягти, використовуючи для цього овочеву сировину (Kovalenko, 2019).
Поповнити баланс життєво важливих для людини макро- і мікронутрієнтів можливо за рахунок цінної високоврожайної культури - гарбуза. Хоча в Україні обсяги вирощування та використання є досить низькими, гарбузи були й залишаються улюбленою овочевою культурою багатьох українців. За останні роки в країнах ЄС значно збільшилось виробництво гарбуза i досягло в таких країнах як Італія - 350 тис. т, Франція, Німеччина - 70 тис. т, Іспанія - 50 тис. т. Гарбуз належить до числа цінних овочебаштанних культур, плоди і насіння якого мають важливе значення як харчові продукти, що забезпечують дієтичне (завдяки високому вмісту каротину, цукрів, мікроелементів, харчових волокон, крохмалю) i лікувальнопрофілактичне харчування (знижують ризик серцевосудинних, онкологічних і шлунково-кишкових захворювань) (Barabolya et al., 2018).

Використання гарбуза різноманітне - від фармацевтичної до харчової промисловості. У харчовій промисловості гарбуз знайшов своє використання у різних видах - як у натуральному, так і у вигляді напівфабрикатів. Тому вміле поєднання тваринної й рослинної сировини $є$ перспективним у соціальному, технологічному та біологічному аспекті.

\section{Матеріал і методи досліджень}

Дослідження проводились в умовах наукової лабораторії кафедри технології м'яса, м'ясних та олійно-жирових виробів Львівського національного університету ветеринарної медицини та біотехнологій імені С.3. Гжицького. У модельних зразках паштетних виробів визначали хімічний склад і комплекс функціонально-технологічних властивостей згідно зі стандартними методиками (Antipova et al., 2001; Zhuravskaja et al., 2001).

Метою роботи було виявлення можливості використання м'якуша гарбуза у виробництві паштетних виробів. Використання рослинної сировини у виробництві м'ясних продуктів дозволяє збагатити їх вітамінами, мінеральними речовинами, харчовими волокнами. Завдяки їхньому застосуванню отримуємо низькокалорійний продукт функціонального призначення.

Печінка використовується в лікувальному харчуванні, оскільки містить білки, вітаміни А, групи В, значну кількість заліза, міді, ліпотропних речовин (метіонін, холін, лецитин). Такий склад дозволяє рекомендувати страви 3 печінки особам, що мають захворювання шкірних покривів, хворим на анемію 3-4 ступеня. Проте в печінці багато пуринів, сечової кислоти і холестерину. Крім того, внаслідок присутності в печінці великої кількості кислих радикалів при іiі 
споживанні кислотно-лужна рівновага в організмі зсувається в кислий бік. Це провокує порушення обміну речовин, сприяє швидшому старінню організму. Тому при споживанні печінку необхідно поєднувати 3 овочами, які не тільки нормалізують кислотність, а й поліпшують перетравлюваність печінки в шлунковокишковому тракті. При розробленні паштету функціонального призначення ми пропонуємо вносити до його рецептури м'якуш гарбуза, який є джерелом харчових волокон та пребіотика інуліну, користь яких добре відома. Гарбуз справляє виражену очисну дію на організм, насамперед виводить 3 крові холестерин та інші токсичні речовини, допомагає видаленню зайвої рідини та солей, що вкрай важливо у разі серцево-судинних та ниркових захворювань.

М'якуш гарбуза містить практично всі 3 відомих вітамінів, а також великий список мікро- і макроелементів. У гарбузі виявлений специфічний вітамін, який отримав назву вітаміну $\mathrm{T}$, що активізує обмінні процеси в організмі. Наявність органічних сполук кремнієвої кислоти у поєднанні 3 іншими біологічно активними речовинами, що пригнічують розвиток палички Коха, дозволяє говорити про гарбуз, як про потужний засіб для профілактики туберкульозу.

Гарбуз складається на з 85-94\% з води. Вуглеводів у складі м'якушу гарбуза 8-12\%. Вміст цукру в основних сортах 4-8\%, а в окремих мускатних сортах гарбуза цей показник може становити до 14\%. Плоди гарбуза містять від 2,5 до 16\% крохмалю, який під час зберігання переходить в розчинні цукри. Клітковини у гарбузі 1,2\%, пектинів - 0,7-1,2\%, органічних кислот - 0,1\%. Гарбуз - справжня скринька мінеральних сполук. Він містить у достатній кількості кальцій, калій, фосфор, залізо, мідь, фтор і цинк. У гарбузовому м'якуші дуже багато каротину, у гарбузі містяться вітаміни групи B, C, E, D, PP, а також рідкісний вітамін T (DSTU 3190-95, 1997; Barabolya et al., 2018).

Таким чином, використання гарбуза (за рахунок його цінного хімічного складу) сприяе можливості для коригування рецептури паштетних виробів з метою одержання біологічно цінної продукції з вираженими функціональними властивостями.

\section{Результати та їх обговорення}

Важливим чинником у вирішенні проблеми щодо захисту населення від підвищеного вмісту важких металів, радіонуклідів, шкідливих відходів виробництва є створення у сучасній харчовій індустрії функціональних продуктів. Майже всі ці продукти, незважаючи на різноманітність своєї хімічної природи чи складу компонентів, являють собою складні системи 3 єдиною внутрішньою структурою та загальними фізико-хімічними властивостями, наявністю конкретних речовин чи функціональних інгредієнтів, що володіють тими чи іншими властивостями. На наш погляд, при створені таких м'ясних функціональних продуктів значний інтерес становить використання рослинної чистої природної сировини, серед яких овочі, ягоди, фрукти, злаки. Вони є джерелом додаткових поживних речовин, які позитивно впливають на здоров'я людини, завдяки кращій засвоюваності поживних та біологічно активних речовин.

Для вирішення поставлених завдань у технології паштетних виробів використовували м'якуш гарбуза бланшований.

До рецептури контрольного зразка паштетних виробів входила: печінка свинна жилована бланшована, щоковина свинна жилована бланшована, мозок яловичий бланшований, мука пшенична, кухонна сіль, перець чорний, мускатний горіх або кардамон.

\section{Таблиця 1}

Рецептури дослідних зразків паштетних виробів

\begin{tabular}{lcccc}
\hline \multicolumn{1}{c}{ Складові компоненти } & Контрольний зразок & Рецептура № 1 & Рецептура № 2 & Рецептура № 3 \\
\hline Печінка свинна жилована бланшована & 22 & 22 & 22 & 22 \\
Щоковина свинна жилована бланшована & 50 & 45 & 40 & 35 \\
М'якуш гарбуза бланшований & - & 5 & 10 & 15 \\
Мозок яловичий бланшований & 25 & 25 & 25 & 25 \\
Мука пшенична & 3 & 3 & 3 & 3 \\
Всього & 100 & 100 & 100 & 100 \\
\hline
\end{tabular}

Для підвищення економічної ефективності виробництва в рецептури дослідних зразків додавали м'якуш гарбуза від 5 до 15\%, що обумовлюється меншою собівартістю даного виду сировини. В дослідах частково замінили щоковину свинну жиловану бланшовану на м'якуш гарбуза бланшований для поліпшення функціонально-технологічних властивостей (ФТВ) паштетів. Рецептурний склад основної сировини контрольного та дослідних зразків паштетних виробів наведений в таблиці 1. Частка кухонної солі, перцю чорного меленого і мускатного горіха або кардамону мелених в дослідних і контрольному зразках не змінювалась.
Виготовлення зразків проводили відповідно до технології приготування фаршу паштетних виробів 3 додавання м'якуша гарбуза бланшованого.

Органолептичні показники паштетних виробів із використанням м'якуша гарбуза наведені в таблиці 2. Аналіз органолептичних характеристик паштетних виробів із м'якушем гарбуза показує, що вони суттєвих змін не зазнали і в основному повністю відповідали нормативним вимогам. Так, колір дослідних зразків має жовтувато-коричневий відтінок, зумовлений наявністю м’якуша гарбуза. Запах паштетів приємний - 3 вираженим ароматом прянощів. Однак у дослідних зразках відчувався легкий запах гарбуза. 
Таблиця 2

Органолептичні показники паштетних виробів

\begin{tabular}{|c|c|c|}
\hline \multirow[b]{2}{*}{ Показники } & \multicolumn{2}{|c|}{ Назва паштету } \\
\hline & $\begin{array}{c}\text { Паштет Столичний вищого сорту } \\
\text { (контрольний зразок) ДСТУ 4432:2005 }\end{array}$ & $\begin{array}{c}\text { Паштет печінковий з м'якушем гарбуза } \\
\text { (дослідні зразки) }\end{array}$ \\
\hline Зовнішній вигляд & $\begin{array}{c}\text { Поверхня паштету чиста та рівна, з незнач- } \\
\text { ним виділенням жиру }\end{array}$ & $\begin{array}{c}\text { Поверхня паштетів чиста та рівна, без } \\
\text { виділення жиру }\end{array}$ \\
\hline Консистенція & Щільна, однорідна & Однорідна, злегка мазка \\
\hline $\begin{array}{l}\text { Вигляд фаршу } \\
\text { на розрізі }\end{array}$ & $\begin{array}{c}\text { Фарш сірого кольору, рівномірно } \\
\text { перемішаний }\end{array}$ & $\begin{array}{c}\text { Фарш з жовтувато-коричневим відтінком, } \\
\text { рівномірно перемішаний }\end{array}$ \\
\hline Смак і запах & $\begin{array}{c}\text { Смак приємний, властивий паштетам, слабо } \\
\text { солений, з вираженим ароматом прянощів, без } \\
\text { стороннього присмаку і запаху }\end{array}$ & $\begin{array}{c}\text { Смак приємний, властивий паштетам, слабо } \\
\text { солений, з вираженим ароматом прянощів і } 3 \\
\text { легким запахом та присмаком гарбуза }\end{array}$ \\
\hline
\end{tabular}

Смак паштетних виробів був слабосоленим з присмаком гарбуза у дослідних зразках. Консистенція дослідного зразка була однорідною, злегка мазкою.

Ще однією важливою групою показників для характеристики паштетних виробів є визначення харчової цінності. Як відомо, згідно з нормативними вимогами всі паштетні вироби, що випускаються м'ясопереробною галуззю в Україні, повинні відповідати певним константам (масовій частці вологи, білка, жиру вуглеводів та мінеральних речовин, енергетичній цінністі).

Показники харчової цінності дослідних зразків паштетних виробів із м'якушем гарбуза наведені в таблиці 3. Аналіз цифрового матеріалу даної таблиці свідчить, що додавання м'якуша гарбуза бланшованого певним чином впливає і на фізико-хімічні характеристики.

Вміст білка в усіх зразках практично не змінювався і перебував на рівні 13,51-14,52\%. Проте вміст жиру зменшувався на 7,17-6,24\% за рахунок введення в рецептуру рослинної сировини. На відміну від контрольного зразка дослідні містили більшу кількість вуглеводів на 1,50-1,68\%. Вміст мінеральних речовин становив 2,26-2,33\% в дослідних рецептурах, що на 0,34-0,41\% вище порівняно 3 контрольним зразком. Енергетична цінність досліджуваних зразків знижувалась 3 підвищенням вмісту рослинної сировини.

Таблиця 3

Показники харчової цінності паштетних виробів

\begin{tabular}{lcccc}
\hline \multicolumn{1}{c}{ Найменування } & Контрольний зразок & Рецептура № 1 & Рецептура № 2 & Рецептура № 3 \\
\hline & & Масова частка, \% & & 13,51 \\
Вміст білка & 14,52 & 13,64 & 13,58 & 20,14 \\
Вміст жиру & 27,31 & 20,86 & 20,46 & 1,82 \\
Вміст вуглеводів & 0,14 & 1,64 & 1,73 & 2,33 \\
Вміст мінеральних речовин & 1,92 & 2,26 & 2,30 & 241,02 \\
Енергетична цінність, & 289,21 & 256,05 & 248,07 & \\
ккал/100 г продукту & & &
\end{tabular}

Таким чином, обгрунтовано доцільність використання рослинної сировини в технології низькокалорійних паштетних виробів.

Функціонально-технологічні властивості м'ясних продуктів - це сукупність показників, які характеризують рівень вологозв'язувальної (В33) та жироутримувальної (ЖУЗ) здатності, що своєю чергою обумо- влюють цілу низку інших параметрів, в тому числі й органолептичні властивості.

Результати оцінки функціонально-технологічних властивостей модельних зразків наведений в таблиці 4.

Вміст вологи у контрольному зразку складав 57\%, у рецептурі № 1 даний показник підвищувався на $4,8 \%$, для рецептури № 2 - на $5,0 \%$, у рецептурі № 3 на 5,3\% порівняно з контрольним зразком.

\section{Таблиця 4}

Зміна функціонально-технологічних показників в залежності від рецептур

\begin{tabular}{|c|c|c|c|c|}
\hline Складові компоненти & Вміст вологи, \% & B33, \% & ЖУЗ, г/Г & $\mathrm{pH}$ \\
\hline Контрольний зразок & 57,0 & 65,10 & 3,74 & 6,10 \\
\hline Рецептура № 1 & 61,8 & 67,96 & 4,04 & 6,17 \\
\hline Рецептура № 2 & 62,0 & 68,08 & 4,08 & 6,18 \\
\hline Рецептура № 3 & 62,3 & 68,22 & 4,12 & 6,20 \\
\hline
\end{tabular}

Дані таблиці свідчать, що найбільша В33 і ЖУЗ була для паштетних виробів за другою і третью рецептурами. Показник активної кислотності для кон- трольного зразка складав 6,10, що на 0,10 менше, ніж у зразку № 3 .

Аналіз отриманих даних дозволяє зробити висновок про те, що рослинна сировина підвищує здатність 
паштетних мас зв’язувати воду й жир. Таким чином, використання м'якуші гарбуза в паштетних виробах доведено з технологічної точки зору.

\section{Висновки}

Аналіз наведених результатів свідчить, що серед дослідних зразків паштетних виробів 3 м'якушем гарбуза найкращими показниками володіє зразок № 3, оскільки, зважаючи на достатню кількість в рецептурі м'якуша гарбуза, співвідношення компонентів дозволяє отримати продукт з низькою калорійністю.

На основі проведених досліджень, можна стверджувати, що заміна щоковини свинної на м'якуш гарбуза дозволяє отримати м'ясну систему з добрими функціонально-технологічними показниками.

Перспективи подальших досліджень. Результати досліджень підтверджують перспективність використання м'якуша гарбуза в технології паштетних виробів. Подальші дослідження будуть спрямовані на визначення функціональних та структурномеханічних властивостей розроблених виробів та розроблення раціональних способів зберігання продукції.

\section{References}

Antipova, L.V., Glotova, I.A., \& Rogov, I.A. (2001). Metody issledovanija mjasa i mjasnyh produktov. M.: Kolos (in Russian).

Barabolya, O.V., Kalashnyk, O.V., Moroz, S.E., Zhemela, H. P., Yudicheva, O.P., \& Serhiyenko, O.V. (2018) Vykorystannya napivfabrykativ harbuza dlya zbahachennya khliba pshenychnoho VISNYK
Poltavs'koyi derzhavnoyi ahrarnoyi akademiyi, 4, 7680. doi: 10.31210/visnyk2018.04.11 (in Ukrainian).

Chamova, Yu.D., Kaynash, A.P., \& Palyy, A.S. (2006). Razrabotka nyzkokaloriynykh myasorastytel'nykh pashtetov. Tez. dop. II mizhnar. nauk.-prakt. konf. "Kharchovi tekhnolohiyi - 2006". Odesa: ONAKHT (in Russian).

DSTU 3190-95 (1997). Harbuzy prodovol'chi svizhi. Tekhnichni umovy. Vved. 01.07.97. K.: Derzhstandart Ukrayiny. http://online.budstandart.com/ua/catalog/docpage.html?id_doc=83697 (in Ukrainian).

DSTU 4432:2005 (2006). Pashtety myasni. Tekhnichni umovy. Natsional'nyy standart Ukrayiny. K. Derzhspozhstandart Ukrayiny. http://ukrapk.com/ gosts/meat/dsty44322005pashtetimquotyasni.html (in Ukrainian).

Kaynash, A.P. (2011). Tovaroznavcha kharakterystyka kovbasnykh vyrobiv z roslynnymy dobavkamy: monohrafiya. Poltava: RVV PUET (in Ukrainian).

Kovalenko, A.M. (2019). Perspektyvy vykorystannya harbuza V kharchoviy promyslovosti. Problemy formuvannia zdorovoho sposobu zhyttia u molodi: zb. nauk. prats molodykh uchenykh, aspir. ta studentiv za materialamy V VNPK, Odesa: ONAKhT, 2, 79. http://dspace.nuft.edu.ua/jspui/handle/123456789/105 58 (in Ukrainian).

Kaynash, A.P., \& Vinnikova, L.H. (2007). PAT. 25521 UA Ukrayina, MPK (2006) A23J 1/00. Protses pryhotuvannya pashtetiv m"yasnykh z ovochevymy dobavkamy. № u 200703851; Zayavl. 06.04.2007; Opubl.10.08.2007, Byul. № 12 (in Ukrainian).

Zhuravskaja, N.K., Gutnik, B.E., \& Zhuravskaja, N.A. (2001). Tehnohimicheskij kontrol' proizvodstva mjasa i mjasoproduktov. M.: Kolos (in Russian). 